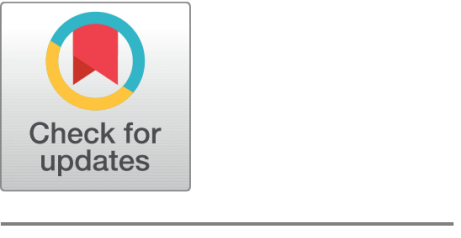

OPEN ACCESS

Received: 17.11.2020

Accepted: 16.12 .2020

Published: 28.12 .2020

Citation: Pagatpatan Jr. AC (2020) Narratives of financially challenged ESSU Guiuan graduates who attained educational and career success. Indian Journal of Science and Technology 13(47): 4619-4630. https://doi.org/

10.17485/IJST/v13i47.2074

* Corresponding author.

Tel: 0917-322-6927

andrespagatpatan@yahoo.com

Funding: None

Competing Interests: None

Copyright: () 2020 Pagatpatan Jr. This is an open access article distributed under the terms of the Creative Commons Attribution License, which permits unrestricted use, distribution, and reproduction in any medium, provided the original author and source are credited.

Published By Indian Society for Education and Environment (iSee)

ISSN

Print: 0974-6846

Electronic: 0974-5645

\section{Narratives of financially challenged ESSU Guiuan graduates who attained educational and career success}

\author{
Andres C Pagatpatan Jr. ${ }^{1 *}$ \\ 1 Campus Administrator, Eastern Samar State University, Guiuan Campus, Guiuan, Eastern \\ Samar, 6809, Philippines. Tel.: 0917-322-6927
}

\section{Abstract}

Background/Objectives: Education lessens the challenges that an individual will face in life. The more knowledge gained, the more opportunities will open up for individuals to achieve better possibilities in their career and personal growth. The purpose of this narrative study was to understand and discover the experiences of financially challenged ESSU Guiuan Graduates attaining educational and career success. Further, the researcher sought to establish a clearer picture of the full story behind how the informants' of this study handled their financial challenges and struggle to make ends meet and afford their education. Methods/Statistical analysis: This study used the narrative inquiry approach to qualitative research. As Czarniawska ${ }^{(1)}$ describes narrative research as an understanding of the narrative account of individual experiences, or series of events/actions, in spoken or in writing which is chronologically connected. In general, this study deals with biographicalresearch as a potent tool into the world of identity, understanding meanings and acquired practical knowledge. Findings: The data gathered generated three themes namely: 1.) Background of their poverty experiences, and has the following sub-themes: a) Relevant Poverty Experiences, b.) Resilience amidst Poverty Experience; 2) Experiences, Challenges, and Highlights of their Life amidst Poverty, and has the following sub-themes: a) Idea and the secret to success, b) Personal Success, c) Idea of Poverty, d) Relevant Experiences of Poverty, e) Challenges and Strategies to Success, 3.) Sense-Making of Personal Success and its sub-themes emerged, namely: a) Life Hardships and Trials, b) Determination and Perseverance, c) Personnel Reflection and Prospect, d) Ideals in overcoming obstacles. Novelty/Applications: This study concluded that the willingness of every individual to conquer and overcome financial challenges with determination and perseverance paved the way for achieving their intended goals and ambitions which eventually leads to self-fulfillment and success.

Keywords: Narratives; financially challenged graduates; educational success; career success; narrative inquiry 


\section{Introduction}

Students from low-income families are significantly less likely to attend college and complete four-year degrees compared to their peers ${ }^{(2-5)}$. As cited by Carter ${ }^{(6)}$, a catastrophic, long-lasting, and generational impact of poverty on children's lives and their families. There are about $20 \%$ of children in the world live in indigence. Mostly, children are regarded as the greatest victims of poverty because of their family's financial situation in which they become powerless to alter. Poverty had an adverse impact on children's opportunities in life and well-being in terms of physical, emotional, social, cognitive abilities, and school achievement ${ }^{(7-10)}$. Moreover, families from low socio-economic status (SES) have been found to have limited financial and educational resources as well as limited access to social and cultural capital. This deficiency in family resources is adversely related to children's well-being ${ }^{(11-13)}$.

In Asia, particularly Singapore, education is an essential way for social mobility ${ }^{(14)}$. Thus, children from low-income families who perform poorly in school have to exert an effort to catch up with their peers or risk remaining within the poverty circle. Further, parents strive for their children to send to private schools to obtain a quality education. It is generally viewed that education in private schools is more beneficial to students as compared to public schools. However, public schools have lower tuition fees than private schools, because public schools have support funds from the government. It is, therefore, an economic burden for mediocre families who have three or more children ${ }^{(15)}$

Also, financial is the hardest problem faced by resource-deprived families. As for them, without money, it hinders them to attain a good future. Usually, there is always hope. Knowingly, poverty is not a hindrance to obtaining success in life. It depends on the person to work hard, to make impossible things possible. Yet, man's determination is a leeway to change one's life and to defeat poverty. If everyone is determined and hardworking, no one is poor.

It is known to most that poverty is the greatest stumbling block to one's education. But to others, consider poverty as a challenge for it doesn't mean that being poor, you don't have the chance to dream big and attain success. However, nowadays, public or state universities and colleges (SUCs) in the Philippines are subsidized and supported by the government under the Republic Act 10931 otherwise known as "Universal Access to Quality Tertiary Education" which gives a full subsidy to students who intend to earn tertiary or technical-vocational education. In other words, economically disadvantaged students can have their education for free. Only that, they should strive hard to beat the odds especially if someone has strong determination.

There are many people who believed that there is no impossible even if you belong to an economically disadvantaged families. And still, some of those people that have inadequate financial resources were able to support their children finish their studies and land a decent job.

With this, the purpose of this study is to explore the stories of Graduates who belong to the economically disadvantaged but still were able to attain success, especially in their academic journey. This study may likewise spawn a plethora of ideas and experiences on how these financially challenged graduates highlighted the meaning of their educational and career success.

The purpose of this narrative study was to understand and discover the experiences of the financially challenged ESSU Guiuan Graduates attaining educational and career success. Further, this narrative inquiry sought to understand that despite the difficulty, the informants were still able to attain success, especially in their academic performance. This also aimed to explore the significance that they attached to emotional situations, important events, and milestones of their lives.

Specifically, this study sought answers to the following questions:

1. In what ways do financially challenged graduates to narrate their experiences in attaining education and career success?

2. How do financially challenged graduates make meaning of their educational and career success?

\section{Materials and Methods}

This study used the narrative inquiry approach to qualitative research. The narrative research design enables the researcher to arrive at an understanding of the research participants' experiences by way of a thorough examination of their life stories. Fraenkel, Wallen, and Hyun ${ }^{(16)}$ explained that an important characteristic of narrative research is the participants' remembering of crucial events in their lives, which they termed as "epiphany." These events are then narrated with respect to time, space, and context (social, political, cultural). In general, this study deals with biographical-research is a potent tool into the world of identity, understanding meanings of individual's experiences and acquired practical knowledge and every day codes present in the process of interrelation, identification, personal and cultural reconstruction ${ }^{(17)}$. Further, in this type of narrative study, the researcher writes and records the experiences of another person's life ${ }^{(18)}$. 


\subsection{Informants of the Study and Site Area}

The researcher purposively selected the ESSU Guiuan Graduates who are financially challenged and were able to attain educational and career success despite being from low-income families. An in-depth interview was conducted with four informants who were chosen based on the set characteristics and objectives of the study.

The informants of this study were the six (6) financially challenged graduates of Eastern Samar State University Guiuan, who were able to attain educational and career success. The informants were selected purposively based on their characteristics and the objectives of the study. Likewise, the researcher identified the informants who could provide insightful information about attaining educational and career success despite being economically disadvantaged persons. Further, the informants' profiles were identified to establish their eligibility as potent sources of responses.

\subsection{Research instrument}

A semi-structured interview guide was used to gather valuable data and information during the in-depth individual interview. The questions were open-ended, structured, and logically arranged. The interview guide consists of two primary questions based on the sequence of the research questions. Each primary question is composed of probing questions to enable the researchers to collect enough, relevant data for the study. However, the researcher allowed a high degree of flexibility since the researcher asked follow-up questions to elucidate some points of the research.

An in-depth interview is a qualitative method of inquiry that uses a pre-determined set of open-ended questions to collect the narratives of human experiences and with the opportunity for the interviewer to explore particular themes or responses. Further, this kind of interview collects detailed information in a style that is somewhat conversational. It is used when the researchers want to delve deeply into a topic and to understand thoroughly the answers provided. Marshall and Rossman ${ }^{(19)}$ posited that an interviewer must possess skills in framing questions and probing for answers.

\subsection{Data gathering procedure and data analysis}

Data collection involves a series of activities the researcher engages in during this phase of study ${ }^{(20)}$. After securing the informants' approval and consent in the conduct of the study through a formal communication letter and consent form, the researcher conducted a three-stage interview process with the informants as suggested by Jowkar et al. ${ }^{(21)}$ in their study of women superintendents in the US. The initial interview stage was conducted to obtain consent and obtain the personal narratives of the participants in view of their leadership and development experiences. The second interview stage was conducted to refine the details of the participants' experiences and for them to be able to reflect on the meanings of their experiences, and thereby providing richer and thicker descriptions. The last interview stage was used as an opportunity for the participants to check the ambiguities of their responses and for the researcher to raise other probes if the need arises. This was made before the writing of the manuscript.

This qualitative study employed the general interview guide to solicit informants' narratives but keep the consistency and the structure of the interview process. The researcher used open-ended questions framed in everyday language to allow informants to provide detailed stories, asking questions verbalized to elicit narratives, and consisting of broad primary questions complemented with probing questions. Each interview session is expected to last at least one to two hours.

Moreover, the researcher took an important role in asking questions from the informants so that the interview process could generate meanings of the informant's experiences. As suggested by Merriam and Tisdell ${ }^{(20)}$ the "researcher is the primary tool for data gathering and analysis", that who should be "responsive and adaptive".

The concepts of responsiveness and adaptiveness refer to the characteristics of the researcher that enable him to effectively capture the important events, moments, and stages of the participants' lives that can be used to answer the objectives set in this study.

Narrative analysis is one of the forms of qualitative data analysis that is commonly used in a narrative study. According to Riessman ${ }^{(22)}$, narrative analysis refers to a family of methods for interpreting texts that have in common a storied form.

Since this study was qualitative, the researcher employed narrative thematic analysis using Creswell ${ }^{(23)}$ strategy as cited by Butina ${ }^{(24)}$. The following five steps were observed to analyse the data gathered: (1) organization and preparation of the data, (2) obtaining a general sense of the information, (3) the coding process, (4) categories or themes, and (5) interpretation of the data.

Further, the researcher used an approach suggested by Ollerenshaw and Creswell ${ }^{(25)}$ that incorporates different elements that go into the story. The elements of narrative analysis involved: collecting the stories of personal experiences in the form of an interview, restorying based on narrative elements, rewriting the stories into a chronological sequence, and incorporating the 
setting or place of the participants' experiences. In the organization and preparation of gathered data, begin with transcribing the audio record from the interview. In collecting stories of informants' experiences, the researcher looked for life-course stages or experiences to develop a chronology of the individual's life from the growing stage of their career until the attainment of their educational and career success. Also, the informants' stories were analyzed. The researcher took an active role in the 'restorying' of the stories by reorganizing the stories into a framework that makes sense. Beyond the chronology, the researcher also looked at the themes that emerge based on the coding process of data. Moreover, themes emerged helped to provide a more detailed discussion of the meaning of the story. This qualitative data analysis is a description of both the story and the themes that emerged.

However, since the goal of the researcher is to understand the experiences of the informants, it is important to use codes, categories, and themes in order to explicate these concepts.

\subsection{Bracketing/ Research reflexivity}

Bracketing is a method used by some researchers especially in qualitative data analysis and interpretation to reduce the potentially deleterious effects of unacknowledged preconceived ideas related to the research and thus to increase the rigor of the study.

Further, bracketing is used to protect the researcher from the cumulative effects of the close relationship between the researcher and the research topic that may develop during the process of qualitative study ${ }^{(26)}$.

Bracketing is holding the elements in abeyance that define the limits of an experience when a researcher/participants are unveiling a phenomenon about what which they want to, and they already know a great deal ${ }^{(27)}$. Moreover, Ahern ${ }^{(28)}$ describes bracketing as a way of demonstrating the validity of the data collection and analysis process.

Hence, to keep away from biases in the interpretation of data and organization of the narratives, this requires the researcher to put aside his own belief about the research topic or what one already knows about the subject before and throughout the narrative study.

However, subjectivity statement is important in qualitative research as Bochner and Riggs ${ }^{(29)}$ explain, "Storytellers always tell their stories to somebody in someplace and the conversational partners and surrounding environment can influence what gets told or doesn't, and how". Thus, it is crucial to consider the kind of interpersonal bond that is created between teller and listener".

\subsection{Enhancement of trustworthiness}

The information acquired by the researcher along the course of the study was treated with strict confidentiality and for academic purposes only. Also, all information will not be used by anyone without the prior consent of the researchers and participants of the study.

\subsection{Ethical consideration}

This study is subjected to certain ethical considerations. First, all the informants were asked to sign consent forms regarding their full participation in this study. These forms assured that the informants voluntarily participated in this research. Also, they were fully informed regarding the objectives of this research and reassured them that this will remain confidential and will be used solely for academic purposes.

\section{Results and Discussion}

\subsection{Themes arrived}

Based on the responses of the informants, the researchers were able to come up with themes using the Creswell narrative analysis approach.

In different ways financially challenged graduates to narrate their life experiences in relation to their personal and professional development. The participants, who are financially challenged individuals, recount various experiences from their early childhood privation experiences until their rise to become successful individuals. This, therefore, provides a rich and detailed background of their lives.

In the narration of the informants on their experiences in obtaining their educational and career success despite the financial challenges they encountered, three themes emerged from the narratives as can be gleaned in the coding grid, namely: 1.) Background of their poverty experiences, and has the following sub-themes: a) Relevant Poverty Experiences, b.) Resilience 
amidst Poverty Experience; 2) Experiences, Challenges, and Highlights of their Life amidst Poverty, and has the following sub-themes: a) Idea and the secret to success, b) Relevant Experiences of Poverty, c) Challenges and Strategies to Success, 3.) Sense-Making of Personal Success and its sub-themes emerged, namely: a) Life Hardships and Trials, b)Determination and Perseverance, c) Personnel Reflection and Prospect, d) Ideals in overcoming obstacles.

\subsection{Theme 1: Background of their poverty experiences}

Findings provide evidence that the informants had poverty experiences even at a very young age. The early life course experience on poverty has a wide range of impacts on the participant's career development and educational success, as well as into adulthood. The participants told their stories on the relevant poverty experiences that enthused them to aim for a better life.

Narratives of all six (6) informants showed experiences of being resource-deprived individuals, how they caught up in their parents' economic struggles to experience and their unmet needs experience. As the participants shared:

\subsubsection{Relevant poverty experience}

Informant 1:

"During my childhood, there were times that we cannot take our meals three times a day due to lack of resources and...we don't have the same resources and luxury with other families..., there were even times that we cannot get and have our wants. Our resource was only enough to provide us with our needs."

Informant 2:

"I witnessed how my parents experienced financial challenges in raising their children, they are just selling ready- to eat foods and snacks to students since our canteen before was stationed near Trade School, now ESSU Guiuan."

Informant 3:

"I was born to a family who was earning through the baking of bread, processing copras (the drying coconut meat), and would even sometimes go on fishing. Unfortunately, one of my siblings got sick and we went through financial crises so I had to hold off studying and bravely decided to work instead."

Informant 4:

"I remember one time, my mother went to Llorente town, brought a coco wine (tuba), dried fish, and wave matt, and went home bringing rice. So even we're 17 children, we can eat complete meals a day, however, meals were divided to us, no refills since our food was just sufficient for the day".

Informant 5:

"I remember when I was in my younger years, many times that our electricity had been cut-off because my parents cannot pay the bills and we have to endure the hardship of studying using a lamp. We have also to walk for almost one kilometer to fetch drinking water and look for firewood elsewhere for cooking our meals".

Informant 6:

"I was raised by my parents helping them make a living while studying my elementary education even at an early age of 6. I help my parents prepare the fruits and vegetables at night, and they sell it in the market the next morning, then I go to school to study".

The informant's narratives proved that informants experience economic challenges with their family; however, despite these, they are still hopeful that they can survive all of these challenges in life.

\subsubsection{Resilience amidst Poverty Experience}

\section{Informant 1:}

"But then again I try to manage myself and bear in mind that the situations I experienced before and coming from a poor family, braved me to gather myself and strive hard. Do whatever is it that we need to do. These made me strong that no matter what difficulty I encountered, I did not give up."

Informant 2:

"I encountered financial challenges especially when I was having my Civil Engineering Board Review at Cebu City so my parents are having difficulty earning money for my allowance and cost of living. Despite the challenges, I was able to finish the review, passed the Board Exam, and became a licensed Engineer."

\section{Informant 3:}

"My only hope than in finishing my studies were through my SK Scholarship and my earnings through driving Pedicab. I was juggling my time between driving part-time and studying. I normally drive Pedicab early through Mornings and every Friday until one time, someone approached me and asked to rent my Pedicab. What I did was, I had someone rent the Pedicap and I applied as a 'Student Laborer' all through summer.'

\section{Informant 4:}


"During my high school, I applied for a scholarship from FFI, luckily, I availed the said scholarship and received an allowance. So, after high school, I tried to enroll in college from different schools. Though I passed the entrance exam from the other schools, I decided to have my college at Trade School. Then I earned my college in the same school and I still have the scholarship to help me fund my studies. At that time I was earning extra income on Saturdays and Sundays, I worked in the construction of "Pa Doming's" house. I graduated from Trade school, so, I have a background in construction work. After my college graduation, I decided to take the Professional Board Examination for Teachers (PBET) now Licensure Examination for Teacher (LET)."

Informant 5:

"During my $2^{\text {nd }}$ year in college, my father died and I have to stop studying to help my mother selling fish and vegetables in the market. But selling fish and vegetables won't give us enough profit to support our basic needs and education. This is due to the unstable weather condition in our place that affects the prices to go high and low. So I look for other forms of income like designing and decorating venues in fiesta and weddings, skirting and serving foods, doing facial makeups to my friends and some acquaintances during occasions."

\section{Informant 6:}

"I was forced to stop on my studies three-times during my college years due to financial constraints and unfortunate sickness of my siblings that is why I have to return to my hometown to help my parents make a living. I did not lose hope despite the difficulty, instead, I look for an extra income by going along with my cousins in fishing and I divide the income I get from that and save some for my education. After 6 months, I return to school and luckily was able to have a scholarship from CHED under the funds from Congressional District Office. That is how I finished my degree in Civil Engineering and it took me 6 fruitful years."

The narratives of the informants illustrate wide-ranging experiences describing resilience, being tough or had the ability of the informants to 'bounce back' from difficulty. Filipinos are often labeled as having a strong adherence to family-oriented values that emphasizes cohesiveness. Conger and Conger ${ }^{(30)}$ conceptualize that "family resilience as processes occur over time in response to a family's specific context/situation and stage of development." Moreover, family resilience viewed as evidenced by certain indicators, such as close and supportive family ties.

\subsection{Theme 2: Experiences, challenges, and highlights of their life amidst poverty}

As financially challenged individuals, they encountered a host of challenges that were able to shape them into who they are now. As they did so, they practiced various skills in consonance with the situation and learned valuable lessons along the way. As opined by Fuller ${ }^{(31)}$, extreme poverty is not the end hope. The important things needed to break down the walls from the imprisonment of poverty are outside influences, support networks such as friends or family, awareness of other opportunities, and accessibility to resources. With these, a new life is possible.

\subsubsection{Idea and secret to success}

\section{Informant 1:}

"Even if you came from a poor family, below the poverty line, don't have the necessary resources, we can only earn what we need, we cannot earn what we want. So from that situation, it makes me stronger for us to achieve success or to achieve my personal goals, to achieve my professional goals, to achieve my life goals."

Informant 2:

"Taking-up a master's degree in hospitality management at Manila (the capital city of the Philippines), you need all the resources especially financial because you need to make sure that is not only the theory that you will acquire, you need to make sure that you will be visiting some industries or establishment under the hospitality industry and one of the challenges really is financial. However, those challenges, including financial challenges should not be the reason why one cannot achieve or one cannot earn a master's degree even though the worst situation happened. Those challenges, financial challenges, I was able to manage despite being poor. Sometimes during my masters journey I limit my expenses, food expenses, and other expenses. I tried to walk from Pasay to Pedro Gil just to reach my delivery institution. But these challenges didn't give me a reason to give up or to stop or otherwise I won't earn my master's degree."

\section{Informant 3:}

"We need not be problematic even if we are going through poverty. Be happy with what you have, and never envy someone else's properties. Do not despair, don't be discouraged with the problems and just because you have so little and simple food on the table, and do not compare yourself to others."

\section{Informant 4:}

"For me, we should be thankful for what we are now. I attained my success for there are people who believe in me. Though we need to exert effort and God will provide you everything you ask for."

\section{Informant 5:}


"It is really hard to face many problems at a time, especially when it comes to financial matters, you really have to do everything and set aside your ego and pride, even ask loans from your enemy if the situation requires you to do so. But just like the storms, all problems shall pass and you just have to endure it because there will always be a rainbow and sunshine after a devastating storm."

Informant 6:

"Problems will always be part of our life, we just need to face it with brave heart, determination, perseverance and of course faith with the almighty. Our faith will strengthen us in times of difficulties and it will give us hope and courage to find ways to overcome all our problems. Education will always be the passport for new opportunities to success"

To get an education is the first step to finding a job and earning income. The lack of education renders many jobless and stuck in poverty lives. The Philippine Statistics Authority released the multidimensional poverty statistics based on an initial methodology. It is called the multidimensional poverty index (MPI) and serves to complement the income-based measure of poverty. The MPI is a measure that intends to capture deprivations on various dimensions. The Education dimension had the largest share or contribution to overall deprivation (MPI) at 36.5 percent and 36.9 percent in 2016 and 2017, respectively ${ }^{(32)}$. Based on statistical data, children who live below the poverty line have lower chances of having school success than their peers ${ }^{(33)}$. Evidently, from the stories shared by the informants, their poverty experiences led to obtaining personal success.

\subsubsection{Relevant poverty experiences, and challenges and strategies to success} Informant 1:

"My parents cannot afford to give our wants only our needs. There were times my parents were fighting. That is why I rather chose to live in my uncle's house while my sisters stayed in other houses. Sometimes I compared myself to my childhood friends who were rich. But then again instead of taking the situation negatively, I used those situations to make me stronger and to achieve my goals toward success. So those worse emotional situations were converted in a positive way wherein I would see to it that this won't happen again. Having that in mind, the worse emotional situation, I manage and think of a positive way wherein I need to manage myself to achieve my goals in life."

\section{Informant 2:}

"Usually, the challenges encountered by my family was on financial. However, my parents worked hard. I helped my parents by grilling the barbecue for it was the source of income for the family. The only thing I learned, I should be wise in facing challenges."

Informant 3:

"My challenge was financially and I was able to overcome it through hard work. I went through a lot of jobs when I was studying. I took other side jobs such as in cargo lifting etc. just so I earn money to fund my studies since I can't expect help from my parents who were not earning well. A lesson from what I've been through, work hard and sacrifice because at the end, you will be the one to harvest the reward."

\section{Informant 4:}

"Hard work needs to be paired with being smart. While being hardworking is already there, be wise and smart to find any chance to help, join organizations and find a scholarship. I say we should look ahead and at a wide range. I would always think of tomorrow and that I need to work. Before, if you give me a paper bill worth 20 pesos, it would last with me for a month. I would either deposit it or it stays safe in between the pages of my book. We may have experienced being spanked and it was painful, but was worth it as it helps you grow older-wiser."

Informant 5:

"Being poor in the midst of challenges and problems is very difficult. It will really make you think of negative thoughts to do some bad things, but with the enlightenment of God and the lessons and good manners taught by our parents and guardians, we shall be able to fight the temptation to do bad things and think of ways how to overcome our problems in the right manner despite any circumstances. I learned that despite of the hardships, choose to be good and do what is right."

\section{Informant 6:}

"My challenge was on the finances since my parents came to a point wherein they have to attend the hospitalization of my siblings and other basic needs to survive in the daily struggle. Being a student at that time was very hard, but I did not falter, I look for extra income that will help me finance my daily needs for my studies. I go fishing at night and study in the morning, and had to do some little favors to my classmates especially on their projects in exchange for a penny."

There are no one-size-fits-all strategy that will lead you to success. Each of us has our own strategies to outdo the challenges in life and obtain success. Though attaining success is enormously difficult, and there are also many obstacles along the way. But one of the best ways to guarantee success is by being aware of what challenges are up against you and making sure you are prepared for them. The study conducted by Kuh, Kinzie, Buckley, Bridges and Hayek's ${ }^{(34)}$ views behavioral engagement, positive emotions as entwined with academic outcomes as dimensions of success. In the informants' narratives, they exemplified their uniqueness in overcoming the hitches in the journey toward success. 


\subsection{Theme 3: Financially challenged individual's sense-making of personal success}

This part answers the raised question of how do financially challenged graduates make meaning of their educational and career success and provides a detailed account of the meanings and ideas which the participants attach to the concepts of poverty to success.

The third theme that emerged out from the narratives of the informants is the Sense-making of Personal Success. This was subsequently derived from the following: a) Life Hardships and Trials - which recounts the different experiences of the participants coming from a low-income family which they describe as something emotional during the course of achieving success in their lives. b.) Determination and Perseverance - which relates despite poverty, they were able to cope up and achieve things they want to. c.) Personal Reflection and Prospects in their Life - which presents an intimate look into their personal lives and plans. d.) Ideals in Overcoming Success - which captures the views of the participants on how to achieve success amidst poverty.

\subsubsection{Life Hardships and trials}

Informant 1:

"It is still fresh in my mind during my childhood. Because I came from a poor family, situations were more emotional. You can experience not eating three times a day, you will feel that you are carrying all the burdens of the world. So instead of thinking about those worse situations, I convert it in a positive way wherein I will see to it that this worse situation will not happen again. Having that in mind, I could manage and think of a positive way for me to achieve my goals in life and to earn so that a worse situation will not happen again. So recalling those saddest situations, it is one of my tools in order for me to be more successful or to reach success. One of the best lessons in life for me is, whatever God's blessings I received; whatever situations or achievements I obtained, I will not forget those people who helped me."

\section{Informant 2:}

"The time that I passed my board exam, I knew that my parents were very proud of me as to them, we're just poor and I'm only the one who could be the breadwinner of the family to help them for my other siblings are not able to finish their studies. Among the three siblings, I'm the only one who finished a degree. From barbecue business, I got my review expenses, any way during my college studies it's free for there are scholarships offered."

\section{Informant 3:}

"Work hard whatever challenges you encountered, all these trials had lee-way to solve it. I remember the trials I had when I considered the offer for the employment of Mano Colon, maybe if I did not accept the offer, I should have passed the board exam just"

\section{Informant 4:}

"I remembered one time, my father brought home a bottle with the design of a dragon, and he was nodding his head with sadness in his face. He was about to deal with that 'antique' and was not able to have that for our family needs and brothers' allowance who were in college at that time. That's how our parents tried all things for family's sake. But it never happened that we're not able to eat in a day because my parents do everything so that our basic needs be provided. Though, only during examination time, they gave money to buy snacks for our recess because their priority was to give us food and other family basic needs."

Informant 5:

"It was in my elementary and high school years that there were times that we don't have food on the table, no electricity, no appliances, gadgets, and communications. Just a simple living trying to eat food three times a day. But I did not want to stay in that kind of living, that is why I make up my mind that I will go to school and finished a degree to change our lives."

\section{Informant 6:}

"It was very hard for me to stop during my second year in college, but I have no choice since my parents cannot afford anymore to finance me. I have negative thoughts that I will end-up as a construction worker or side-walk vendor, however, with my constant prayer and the grace from God, I was able to find extra income and return to college and little by little I manage to support my studies. It was very hard and tiring since I work at night and study in the morning, but I keep in my mind that no matter how hard and difficult life, I will finish my studies and become an engineer."

The informants shared their hardships and trials before they attained educational and career success. In a study conducted by Harrell, which was cited by Kpolovie, Joe, and Okoto ${ }^{(35)}$, attitude means everything in handling difficulties in life. Having a cheerful disposition towards every challenge life throws at you can lift the burden off your shoulders. Their stories suggest that despite all these trials, maintaining a positive disposition helped them turn their situations for the better.

\subsubsection{Determination and perseverance}

\section{Informant 1:}


"A lesson I can share is that don't be afraid of facing difficulties, do not come up with a decision or do not think that you cannot do it, do not think that you cannot achieve it. Instead, people who came from poverty make it a tool because again, I can say those poor families are really stronger have a lot of survival skills compared to those people who are rich. Why? Because they suffer from the situation. Use those kinds of experiences to achieve success or to improve our way of living. As of now, whenever I have a lecture with my students, at the beginning of the lesson, I share with them my experiences to motivate them and make them realize the real situation."

Informant 2:

"I am not expecting that I could attain my goal considering that we are poor. The lesson I've learned is that poverty is not a hindrance to success, it depends on how you spend the effort to obtain success in life. Another thing I've learned is, never give up whatever difficulties you encountered and you must be straightforward with your ambition and never stop."

\section{Informant 3:}

"To attain success in life, we must have perseverance, not be indolent, and should not be worried about our economic status for if we are determined to be successful in the near future, we have to sacrifice and be hardworking. Obtaining success depends on the person on how he deals with his life, even though you're not from a rich family but then you are striving for a better life, then you will obtain it. Focus on your ambition if you want to be successful."

Informant 4:

"Work for a dream to become true that is commonly heard among people. Then add hard work and perseverance to attain success. I learned a lot from my experiences, and instill this in my family. We must love our work and our family and we will receive returns for whatever we do."

\section{Informant 5:}

"You need to be disciplined and determined enough to achieve your goal. Even if it is hard and difficult, just continue working hard even just with little progress because it is better than having no progress at all. And in order to attain success, you must start doing something and do not wait for miracles to happen."

\section{Informant 6:}

"Work hard to achieve your goals. Do not let the problems hinder yourself from moving forward, do not stop even you are tired and exhausted, just take a break and take some rest. Stop only when you are done and you have already achieved your goal."

The narratives illustrate the perseverance and determination of the informants. Their collective story deals with the steadfastness in doing something despite difficulties and delays in achieving success. In the study by Madhlangobe et al. ${ }^{(36)}$ perseverance, persistence, among others despite adversities in life can lead one to success. Likewise, having a firm or fixed intentions will help in attaining success.

\subsubsection{Personnel reflection and prospect Informant 1:}

"I have many prospects in life as of now gaining master's degree of course is just part of my dreams. I also have a lot of goals in life but as of now, I cannot say to myself that I am not yet a successful individual because I am still suffering from situations like lack of professional skills, lack of personal skills, lack of life skills. Maybe ten years from now I can achieve my professional goals because as I have earned a master's degree, and maybe ten years from now I will make sure that I can earn a doctorate degree or PhD degree as my professional goals."

\section{Informant 2:}

"I may be ten years from now I will still be in DPWH. Maybe then, I will be in a managerial position. At this time, I belong to the rank and file position. After ten years maybe those who are in a high position will be in their retirement so by then I will have the opportunity in lieu of their vacated position."

\section{Informant 3:}

"In ten year- time, maybe I could fulfil my dreams, I still have dreams to achieve ten years from now, to own a beautiful house, a lot where my house will be erected. Though I already own a house I want a house that is safe for typhoon and earthquake."

\section{Informant 4:}

"Ten years from now, I will be on the stage of my retirement. That time I will be now a grandfather. Then, maybe I will have at least three passive income, my pension, I'm wanting that in ten year-time, I have my own income daily so that I would not indulge to make loans and will receive in full."

\section{Informant 5:}

"I have many dreams in life, and I want to fulfill some of those in the future. Ten years from now, maybe I'll have my own business, I guess catering and decoration services for different occasions. It has been my passion since I was a kid, and that helps me a lot to finish my degree in college." 


\section{Informant 6:}

"Maybe ten years from now, I'll have my own house and family. Also by that time, I hope five of my siblings are already finished with their studies and somehow I will be unleashed from the burden on their finances. I'll be focusing on my own family and keep on working hard to save for the future of my kids so that they will not experience the hardships as I did in my elementary, high school, and college years."

The informants told their stories and reflected on their personal experiences and their prospects in life. Brocket and Hiemstra ${ }^{(37)}$ stated how imperative self-direction in attaining success in life. Strategies in facilitating self-directed learning to enhance the ego within us.

\subsubsection{Ideals in overcoming obstacles Informant 1:}

"You know having this experience in life wherein I've faced problems, a worse situation that sometimes- I could not take meals three times a day, my message to students who come from a poor family and are struggling from a worse situation or facing some problems is that be stronger and come-up with a goal in life. Stronger in a way that if you have goals in life you need to make sure that you will not suffer the same situation that you're experiencing right now, you need to make sure that, that situation or experience will not happen anymore in the coming years."

\section{Informant 2:}

"... whatever difficulties we encounter, we should never stop, we should strive more for us to finish our studies, likewise achieve our dreams and we can help our parents to augment their means of living."

\section{Informant 3:}

"We need to study hard to finish the degree, though we are poor, poverty is not a hindrance to finishing our study and earned a degree, it depends on how determined we are, that if you wish to be an engineer, you have to focus on their studies. Being poor, we should strive hard to improve our standard of living and have focus. There are times that my classmates invite me to go to the beach but then I would refuse to go for I knew that there is a contribution, which I cannot. However, my classmates would be told me, It is okay if you don't have money for our contribution. So I advised those who want to be an engineer, to focus on their studies. You will be the one to benefit from all of your sacrifices."

\section{Informant 4:}

"Don't aim if you think it's an impossible dream. You have to think about how you are going to work, in what way you will attain that, what are your strengths, weaknesses, opportunities, and not threats. Also, you must have a clear direction or path to walk and be guided. Know yourself then from that analysis you will know the better version of yourself. If you are version 2 today, tomorrow you must be a version 3. Do not remain constant for the rest of your life. Like in other online businesses, you don't have the capital, only you need is to be smart."

\section{Informant 5:}

"Don't take life as a race, just work hard, and focus on your dreams, little by little you will be able to achieve those goals before you know it. Do not be afraid to commit mistakes and fail, instead, have the courage to always stand up after every fall and learn from all your mistakes to improve yourself to be better. Lastly, don't compare yourself to others, compare yourself to who and what you are yesterday."

\section{Informant 6:}

"Do not think negatively, accept all problems, and face it with a brave heart and mindset that you will be able to surpass it with the grace of God. You must set your goals, and work hard little by little according to your plan. It is okay to sacrifice some of your free time and hobbies because, in the end, you will reap the fruit of your labor which is a success."

The narrative points out that it often seems like the only constant in life is the challenges standing between you and your goals. Narratives littered with examples of people who have managed to overcome and thrive on the struggles they experience. However, the struggles faced by the informants offer them a path to growth and success.

\section{Conclusion}

This study raised questions to explore the experiences of financially challenged Eastern Samar State University Guiuan graduates in attaining their educational and career success. Following the reflexive, emotional and interpretive nature of account request, the members' biographies, and their experiences from the growing stage of their career until the attainment of their educational and career success which are thusly introduced in a procedure called "re-storying".

The narratives of the six informants provided evidence of their poverty experiences even at a very young age. The experience of poverty early in the life course has far-reaching impacts on the participant's career development and educational success, as 
well as into adulthood. The participants shared their stories on the relevant poverty experiences that enthused them to aim for a better life. However, despite the financial challenges, the informants are still hopeful that they can survive all of these challenges in life.

Their narratives depicted that individual learning experiences over the life span developed sets of skills, such as problemsolving skills, work habits, emotional response, and cognitive responses which are used in coping with the environment and in the struggles of their journey towards success.

Sense-making of personal success of the informants recounts the different hardships and trials during achieving success in their lives; however, they were able to cope with and achieved things they want through determination and perseverance. Evidently, from the informants' narratives, their stories dealt with the steadfastness in doing something despite difficulty or delay in achieving success. However, informants shared their ideas on the concepts of how perseverance and determination paved the way to success.

There was also a strong sense of pride as they spoke about their families. The participants highlighted that despite being labeled by society as "low-income" and being aware of their families' financial struggles, they refused to see their families as poor or identify as economically disadvantaged as it was not part of their lived experiences.

It is recommended, therefore, that the accessibility to quality education must be among the top priorities of political leaders and educational leaders to allocate more funds for continuous improvement of higher education institutions (HEIs) and draft policies that will strengthen the delivery and accessibility of education. They shall focus on providing equal opportunities to everyone especially the deprived and less fortunate sectors.

\section{Acknowledgement}

The researcher is greatly indebted to the many individuals who directly and indirectly contributed to the success of this paper and to the six informants who spared their time and generously shared their stories. Lastly, the researcher would like to acknowledge Eastern Samar State University for the supports to make this research endeavor a reality.

\section{References}

1) Czarniawska B. Narratives in social science research. Thousand Oaks, CA. Sage. 2004.

2) Castleman B, Page L. Summer Melt: Supporting Low-Income Students through the Transition to College. Harvard Education Press. 2014. Available from: https://eric.ed.gov/?id=ED568799.

3) Elliott W. The effects of economic instability on children's educational outcomes. Article in Children and Youth Services Review. 2013. Available from: https://www.researchgate.net/publication/257043069.

4) Navarro D. Supporting the students of the future. Change. 2012;44(1):43-51. Available from: https://doi.org/10.1080/00091383.2012.636004.

5) Posselt JR, Jaquette O, Bielby R, Bastedo MN. Access without equity: Longitudinal analyses of institutional stratification by race and ethnicity. American Educational Research Journal. 2012;49(6):1074-1111. Available from: https://doi.org/10.3102/0002831212439456.

6) Carter B. Child Poverty: Limiting children's life chances. Journal of Child Health Care. 2014. Available from: https://journals.sagepub.com/doi/10.1177/ 1367493514522726.

7) Brooks-Gunn J, Duncan GJ. The Effects of Poverty on Children. The Future of Children. 1997;7(2):55-55. Available from: https://dx.doi.org/10.2307/ 1602387.

8) Dahl GB, Lochner L. The Impact of Family Income on Child Achievement: Evidence from the Earned Income Tax Credit. American Economic Review. 2012;102(5):1927-1956. Available from: https://x.doi.org/10.1257/aer.102.5.1927.

9) Gruber J. The problems of disadvantaged youth: An economic perspective. 2009. Available from: http://www.nber.org/chapters/c0585.pdf.

10) Lee JS. The effects of persistent poverty on children's physical, socio-emotional, and learning outcomes. Child Indicators Research. $2011 ; 4(4): 725-747$. Available from: https://doi.org/10.1007/s12187-011-9120-8.

11) Bradley RH, Corwyn RF. Socioeconomic Status and Child Development. Annual Review of Psychology. 2002;53(1):371-399. Available from: https: //dx.doi.org/10.1146/annurev.psych.53.100901.135233.

12) Claro S, Paunesku D, Dweck C. Growth mindset tempers the the effects of poverty on academic achievement. Graduate School of Education, Standford University. 2016

13) Watkins CS, Howard MO. Educational success among elementary school children from low socioeconomic status families: A systematic review of research assessing parenting factors. Journal of Children and Poverty. 2015;21(1):17-46. Available from: https://dx.doi.org/10.1080/10796126.2015.1031728.

14) Ong XL, Cheung HS. Schools and the class divide: An examination of children's self-concept and aspirations in Singapore. Singapore. Singapore Children's Society. 2016.

15) Chaudhry AQ, Hassan SM. Financial Problems Faced by the parents of the students studying in private schools of Lahore City. Science International (Lahore). 2014;26(5):2531-2534.

16) Fraenkel J, Wallen N, Hyun H. How to design and evaluate research in Education. 8th ed. and others, editor;McGraw-Hill Education. 2011.

17) Bolivar A, Domingo J. Biographical-narrative Research in Iberoamerica: Areas of Development and the Current Situation. Forum: Qualitative Social Research. 2006;7(4):114-0604125. Available from: http://nbn-resolving.de/urn:nbn:de:0114-fqs0604125.

18) Creswell J. Qualitative Inquiry and Research Design: Choosing among five approaches. SAGE Publications, Inc. 2013.

19) Marshall C, Rossman GB. Designing Qualitative Research. 4th ed. Thousand Oaks, CA. Sage. 2006.

20) Merriam SB, Tisdell EJ. Qualitative Research: A Guide to Design and Implementation. 4th ed. Bass J, editor;San Francisco, CA. Jossey Bass. 2016. 
21) Jowkar B, Kojuri J, Kohoulat N, Hayat AA. Academic resilience in education: The role of achievement goal orientations. Journal of Advances in Medical Education \& Professionalism. 2014;2(1):33-38.

22) Riessman CJ. Narrative methods for the human sciences. Thousand Oaks, CA. Sage Publications. 2008.

23) Creswell JW. Research design: qualitative, quantitative, and mixed methods approaches. Thousand Oaks, CA. Sage. 2014.

24) Butina M. A Narrative Approach to Qualitative Inquiry. American Society for Clinical Laboratory Science. 2015;28(3):190-196. Available from: https://dx.doi.org/10.29074/ascls.28.3.190.

25) Ollerenshaw JA, Creswell JW. Narrative Research: A Comparison of Two Restorying Data Analysis Approaches. Qualitative Inquiry. 2002;8:329-347. Available from: https://dx.doi.org/10.1177/10778004008003008.

26) Tufford L, Newman P. Bracketing in Qualitative Research. Qualitative Social Work: Research and Practice. 2012;11(1):80-96. Available from: https: //dx.doi.org/10.1177/1473325010368316.

27) Ray MA. A philosophical method to study nursing phenomena. In: Leininger MM, editor. Qualitative research methods in nursing. Grune \& Stratton. 1985;p. 81-92.

28) Ahern KJ. Pearls, Pith, and Provocation: Ten Tips for Reflexive Bracketing. Qualitative Health Research. 1999;9(3):407-411.

29) Bochner AP, Riggs NA, Oxford library of psychology. The Oxford handbook of qualitative research. Leavy P, editor;Oxford University Press. 2014.

30) Conger R, Conger K. Resilience in Midwestern Families: Selected Findings from the First Decade of a Prospective, Longitudinal Study. Journal of Marriage and Family. 2004;64(2).

31) Fuller L. Poverty relief, global institutions, and the problem of compliance. Journal of Moral Philosophy. 2005;2(3):285-297. Available from: https: //doi.org/10.1177/1740468105058156.

32) Philippine Statistics Authority. 2018. Available from: https://psa.gov.ph/content/filipino-families-are-most-deprived-education- 0 .

33) Operation Warm. 2020. Available from: https://www.operationwarm.org/newsroom/blog.html.

34) Kuh GD, Kinzie J, Buckley JA, Bridges BK, Hayek JC. What matters to student success: A review of the literature. In: Commissioned report for the National Symposium on Postsecondary Student Success: Spearheading a Dialog on Student Success. Washington, DC. National Postsecondary Education Cooperative. 2006.

35) Kpolovie PJ, Andy IJ, Okoto T. Academic achievement prediction: Role of interest in learning and attitude towards school. International Journal of Humanities Social Sciences and Education (IJHSSE). 2014;1(11):73-100.

36) Madhlangobe L, Chikasha J, Mafa O, Kurasha P, Persistence. Perseverance, and Success (PPS) A Case Study to Describe Motivational Factors That Encourage Zimbabwe Open University ODL Students to Enroll, Persist, and Graduate with Master's and Doctorate Credentials. SAGE Open. 2014;4(3):115. Available from: https://doi.org/215824401454429.

37) Brockett RG, Hiemstra R. Self-direction in adult learning: Perspectives on theory, research and practice. London: Routledge. 2018. 